DOI: https://doi.org/10.4796o/2303-7431.24.2020.104

UDK: 392.3:159.9"1809/1918“"

$930.85(436)$ “1809/1918“

Izvorni znanstveni članak

Primljen 6. XI. 2020.

Prihvaćen 11. III. 2021.

IVANČICA MARKOVIĆ

Sveučilište Josip Juraj Strossmayer u Osijeku, Fakultet za odgojne i obrazovne znanosti

imarkovic@foozos.hr

\title{
UTJECAJI PROSVJETITELJSTVA NA OBITELJ, BRAK I BRAČNE ODNOSE NA PROSTORU HABSBURŠKE MONARHIJE
}

\section{Sažetak}

Rad analizira navike i običaje u Slavoniji koji su vezani za obitelj, brak i bračne odnose u 18. stoljeću. Autorica se koristi opisima iz putopisnih i književnih djela te opisima iz izvorne arhivske građe. Uspoređuje ih sa zakonskom odredbom Josipa II. o braku i bračnim odnosima i katekizmom. Isto tako, analizira postoji li i kakva je međusobna povezanost slavonskoga ćudoređa s donošenjem ženidbene uredbe cara Josipa II., odnosno je li zakonska odredba bila samo posljedica sveobuhvatnih prosvjetiteljskih reformi.

Ključne riječi: brak; obitelj; bračni odnosi; zakoni; Habsburška Monarhija

\section{Uvod}

Uzajamno razumijevanje svih članova obitelji i skladni bračni odnosi vrlo su često bili i garancija političke stabilnosti. Mijenjanjem kulturnih, 
političkih i gospodarskih prilika mijenjali su se i odnosi u obitelji te su doživljavali transformaciju. Ti su procesi zabilježeni i u Slavoniji tijekom 18. stoljeća. Upravo tada, u razdoblju prosvjetiteljstva, nastupa velika prekretnica za brak i bračne odnose u zakonodavnome smislu. Naime, Rimokatolička Crkva je nakon Tridentskoga koncila u 16. stoljeću uvela pravilo da je brak priznat i valjan jedino ako je sklopljen pred katoličkim svećenikom i svjedocima. ${ }^{1}$ Međutim, tijekom 18. stoljeća dolazi do postepene sekularizacije bračnih odnosa. Austrijski car Josip II. od 1781. do 1783. uređuje obiteljske odnose, a kao rezultat izdana je Ženidbena $u r e d b a^{2}$ koja je stupila na snagu 1787 . godine. Njome je institucija braka stavljena pod nadzor države i time je prestala biti dio crkvenoga pitanja. ${ }^{3}$ Prema zakonskoj odredbi supružnici se promatraju kao ravnopravni, a za nepoštivanje pravila bile su propisane kazne, pri čemu Josip II. nije pravio razliku između supružnika. Iako je ovom Uredbom brak stavljen u okvir građanskoga prava, etičke su postavke i dalje bile u duhu crkvenoga nauka. To se najbolje vidi usporedbom Ženidbene uredbe s katekizmom, kao što je Uputjenje katolicsansko ${ }^{4}$, o čemu će u daljnjem tekstu biti više govora.

\section{Obitelj i brak - crkveno i običajno pravo}

\section{1. Ćudoređe - jamac državne sigurnosti}

Dugotrajna osmanska vlast ostavila je posljedice na moralne osobine stanovnika Slavonije. Bilo je puno lakše provoditi gospodarske i upravne reforme nego mijenjati običaje i životni stil. Svadbe, vjerski blagdani, kola i prela bili su oblici društvenoga povezivanja. Takva društvenost često je rezultirala velikom razuzdanošću koja je doprinosila stvaranju ozračja nesigurnosti i tako već nesigurna područja. Isto tako, pretjerana

Usp. Anton Benvin, „Obitelj kroz povijest“, Bogoslovska smotra, Zagreb, god. XLII. (1972.), br. 1., str. 46 .

$2 \quad$ Josip II., Mi Josef Drugi (...), Beč, 1786., Nacionalna i sveučilišna knjižnica u Zagrebu, Zbirka rijetkosti, L IV A 9/2 adl 4.

3 Usp. A. Benvini, $n$. dj., str. 46.

$4 \quad$ Uputjenja katolicsanska, u razgovore sloxena, u tri dila razdiljena po Francesku Amatu Pouget, 3. dio, (prev. Ivan Velikanović), Tiskara Ivana Martina Divalt, Osijek, 1788. 
sklonost hedonizmu i opuštenomu životu nije išla u prilog gospodarskomu napretku. Sve te nedostatke vlast je nastojala iskorijeniti ili ih držati pod kontrolom donošenjem različitih propisa.

Marija Terezija i Josip II. postupno su mijenjali svijest ljudi u Monarhiji provođenjem reformi te su tako utjecali na prihvaćanje novih navika i razmišljanja. Do pojave prosvijećenoga apsolutizma crkveno je učenje bilo jedino mjerodavno za ponašanje ljudi, koje je vrlo često bilo u suprotnosti s njim. Stoga se trebalo raditi na mijenjanju vrlina njezinih stanovnika. Habsburgovci su svojim političkim djelovanjem išli za time da od novostečenoga rubnog dijela Monarhije stvore potpuno siguran prostor za život. U tome smislu Crkva kao moralna vertikala nije bila dovoljna. Velika materijalna i duhovna zaostalost bila je popraćena čestim izgredima i protivljenjima jer je njihovo poimanje života bilo $\mathrm{u}$ suprotnosti od poimanja vladajućih. Zato su tijekom 18. stoljeća Marija Terezija i Josip II. donijeli čitav niz zakona koji su u sebi sadržavali sustav kažnjavanja za svaki oblik kršenja zakona. Slavonski su se književnici također u svojim djelima uključili u prosvjetiteljska nastojanja svojih vladara u pravcu stvaranja „novoga“ morala.

U ćudorednome, moralnome i političkome smislu za državu je izrazito važno bilo uređenje braka i bračnih odnosa. Brak je kroz povijest bio društveno prihvaćen model unutar kojega su se ostvarivale osobne potrebe supružnika, od emocionalnih i tjelesnih do ekonomskih i egzistencijalnih. Pored toga njime je bio definiran i društveni položaj pojedinca, što se osobito odnosilo na dobivanje potomstva kao i osiguravanje njihove skrbi. „Zakonito“ potomstvo bilo je moguće jedino u braku, stoga su bračna zajednica i obitelj bile temelj društva u cjelini i u 18. stoljeću. „Smatralo se da zreli muškarci i žene mogu živjeti časno jedino ako su u braku. Na neoženjene i neudane žene uvijek se gledalo sa sumnjom kao na osobe koje su podložnije nećudorednom životu. ${ }^{\text {"5 }}$

Robert Skenderović, Najstarija matična knjiga brodske župe Presvetog Trojstva (17o1.1735.), Hrvatski institut za povijest, Podružnica za povijest Slavonije, Srijema i Baranje, Slavonski Brod, 2012., str. 212. 


\subsection{Brak u književnim djelima slavonskih pisaca 18. stoljeća}

Nimalo čedan i po mnogočemu razuzdan život po slavonskim selima kritizirali su književnici 18. stoljeća: Matija Antun Relković u svome djelu Satir iliti divji čovik i Vid Došen u Aždaji sedmoglavoj. Zapažaju kako je obiteljski život protkan hedonističkim shvaćanjem braka što nije donosilo dobro ni pojedincu ni cjelokupnoj zajednici. Obojica su kritizirala slavonske običaje u kojima se izražavala ženska prpošnost i razuzdanost, ali i muška neukrotivost i buntovnost. Za njih su slavonski običaji bili ogledalo slavonske priprostosti te su se trebali mijenjati.

Za Relkovića su glavni rasadnici ženske i muške raskalašenosti bili kolo i prelo koji su trajali do u kasnu noć:

Oni (tj. momci) obnoć oko kola kašu,

A kad lipo sve okolo opašu,

Onda stražnji pridnjima omahne

I sve kolo na zemlju obvale,

Pa kad bude od divojak hrpa

Onda zgrabiv svaki svoju drpa... ${ }^{6}$

U moralnome smislu stanovnicima je nedostajalo ustrajnosti, razboritosti i osobne discipline. Dugotrajna osmanska vladavina rezultirala je materijalnom oskudicom i duhovnom krizom. Umjesto vjere i borbe za kvalitetniji život, utjehu su pronalazili u neobuzdanim običajima, bježeći od odgovornosti. Unatoč naporima prosvijećenih vladara, Marije Terezije i Josipa II., ćudoređe se sporo mijenjalo. Utjehu od razočaranja i uloge žrtve žitelji Slavonije pronalazili su u kolima, prelima, pjesmama, svadbama, babinjama, nerijetko bježeći i neodgovorno se odnoseći prema svakodnevnim obavezama.

Stoga Došen kao i Relković ukazuju na identične probleme. Došen je želio da Slavonija, Slavonci i Slavonke, promijene svoju zaostalost, nepoštenje, obijest, loše higijenske navike, sklonost prevarama i općenito svoju primitivnost. ${ }^{7}$

Tomo Matić, Slavonske književno - povijesne teme, Riječ, Vinkovci, 2003., str. 103.

7 Usp. VID DošEn - ANTun IvAnošić, Izabrana djela, Slavonska naklada Privlačica, Vinkovci, 1994., str. 67. 
Poznavajući ondašnju Slavoniju (odlazak na prela, pretjeranost u jelu i piću), upozoravao je na sve posljedice takva uživanja, pri čemu je često ismijavao duhovnu i tjelesnu zaostalost Slavonije.

Kori prelo i beside

Gdi s divojkoam momci side

I smrad bludni tamo bljuju

Sebe smradno dok otruju. ${ }^{8}$

Oštro je kritizirao slavonsku neumjerenost u gošćenju prigodom babinja, podušja i svatova, na krštenjima i sajmovima. Naročito je zamjerao veliku raskalašenost žena i djevojaka s muškarcima te pojavu namjernih pobačaja.

Običaji su nepošteni

Već zaleže i ošteni

Bludnost mladež da nagrdi

Pelenam dokle smrdi,

Još balavu nosi bradu,

A o bludnom radi smradu...9

Došen u svadbama, kao i Relković, vidi rasadište nemoralna ponašanja.

Oni kad se pouspenje

priko sedla viseć stenje

i popriko s konja visi

dok mu ručak u nos klisi...

Oni vije, oni viče

Oni reve, oni riče... ${ }^{10}$

Iako se u 18. stoljeću držalo, kako je već navedeno, do „zakonitoga“ potomstva, tj. rađanja unutar bračne zajednice, ovakva ponašanja često su rezultirala „nezakonitom“ djecom. U krajiškome dijelu Slavonije vojna je uprava bila obvezna voditi računa o rađanju nezakonite djece, pa kada bi se doznalo da je koja djevojka ili udovica zanijela, kumpanija bi je pozvala na preslušavanje da se utvrdi tko je otac, ali i da se majci i djetetu prije poroda osigura pomoć. Koliko god je to nastojanje krajiških

\footnotetext{
8 Isto, str. 8.

$9 \quad$ Isto, str. 24.

10 Isto, str. 70.
} 
vlasti socijalno bilo opravdano, nije se kod takvih preslušavanja postupalo osobito obzirno i diskretno. ${ }^{11}$

Taube također ukazuje na neke pojave koje su se negativno odražavale na opstanak bračne zajednice, kao što je običaj da mladoženja kupi nevjestu od njezina oca. Otac je mladenku prodavao onomu tko je ponudio najviše novaca, a razvratnost i povreda bračne vjernosti s obje strane bile su česte. ${ }^{12}$

Sklapanje dogovorenih brakova bile su česte. U pozadini su najčešće bili ekonomski razlozi: stjecanje radne snage, nasljeđivanje, povećavanje imovine - miraz, a želje mladenaca nisu se uzimale u obzir.

Za Matiju Antuna Relkovića dogovoreni brak predstavlja glavni izvor neslaganja i sukoba. Takva zajednica zadovoljava interese samo jedne strane, one roditeljske, ali ne i bračnih drugova.

Ako Ivka pojde za Marjana,

Vidit ćete do malo vrimena,

Da će on nju svaki dan biti.

Jer kako će silom ju ljubiti,

Kad njegova nije bila volja,

Jer Marica njem' se čini bolja.

Jer kad vi svog sina ženite,

Ne pitate niti mu velite,

Je li njemu divojka u volji,

Hoće l'živit s njom u dobroj volji;

Neg tražite sebi prijatelja i prosite, gdi je vami volja. ${ }^{13}$

U braku i obitelji Relković vidi životni smisao koji od oba bračna partnera zahtijeva ispunjavanje određenih dužnosti i obveza. To je, prije svega, međusobno poštivanje koje će onda rezultirati očuvanjem složne i funkcionalne obitelji.

${ }^{11} \quad$ Usp. Tomo Matić, Prosvjetni i književni rad u Slavoniji prije preporoda, Slavonsko selo u djelima hrvatskih pisaca potkraj osamnaestoga vijeka, Slavonska naklada Privlačica, Vinkovci, 1994., str.77.

12 Usp. Friedrich Wilhelm von Taube, Istorijski i geografski opis Kraljevine Slavonije $i$ Vojvodstva Srijema, Lajpcig, 1777., ( preveo s njemačkog Boško Petrović), Matica srpska, 1998., str. 56. -57 .

13 Matija Antun Relković, Satir iliti divji čovik, Kraljevska zemaljska tiskara, Zagreb, 1909., str. 76. -77 . 
Ali kako ti ženu isprosiš,

Ta za brigu odmah $i$ ositiš... ${ }^{14}$

Žena u braku mora imati materijalnu i emocionalnu sigurnost, a oba bračna partnera trebaju ostvarivati sve svoje potrebe. Obitelj je zajednica koja se mora štititi, a žena uvažavati i poštivati:

Tako valja da se ženom staraš

I u tugi s njome razgovaraš,...

To ne valja da ti nju progoniš

I nogama ko robinju gaziš. ${ }^{15}$

Prema Relkoviću, brak je najviše trpio zbog ljubomore i ogovaranja, kako od samih bračnih drugova tako i od okoline. Bračnoj zajednici svrha je bila ostvarivanje sigurnosti svih njezinih članova, muža, žene, a osobito djece. Sloga i mir u kući mogli su se postići samo podrškom i razumijevanjem. Svako je nasilje, prema Relkoviću, za osudu, ni fizičko ni psihičko obračunavanje između supružnika nije imalo opravdanja.

Ako od njih kojegod posrne,

I onaj se drugi kraj privrne.

Ona veli: „Slušajte, komšije,

Je li pravo, da me čovik bije?

On svaku noć po svem selu hoda,

A besposlen ko kakvi uhoda,

Pak na druge svaku večer troši... ${ }^{16}$

Nerad, nasilje i pretjerano trošenje utjecali su na stvaranje loših bračnih odnosa koji su se najčešće rješavali fizičkom silom. Brak je za Relkovića svetinja koju treba njegovati, a za to su odgovorna oba bračna partnera.

Nego s njome u ljubavi živi

I sam sebe za nepravdu krivi,

Pak odsele ne hodaj po noći,

Nego gledaj svu kuću pomoći;

Dobro radeć mlade nagovaraj

I svojim se drugom dogovaraj. ${ }^{17}$

\footnotetext{
Isto, str. 110.

Isto, str. 111.

Isto, str. 113.

Isto, str. 114.
} 


\section{Obitelj i brak - zakonska regulativa}

\subsection{Kontrola bračne zajednice}

U 18. stoljeću spolna aktivnost bila je dozvoljena samo unutar braka. Jedino su takva djeca bila „zakonita“. Djeca koja su se rađala izvan bračne zajednice bila su „nezakonita“ pa su često ostavljana kao siročad, a nerijetko su se događala i čedomorstva. Izvanbračno dijete je za majku i njezinu obitelj predstavljalo veliku „sramotu“ u smislu društvenoga izopćenja i nezaštićenosti. Status takve djece $u$ društvu bio je u potpunosti marginaliziran. Teško su se školovali, zapošljavali i zasnivali vlastitu obitelj. Čak su im i cehovska pravila zabranjivala šegrtovanje jer su budući obrtnici mogli biti samo iz ćudorednih obitelji. ${ }^{18}$

Brak je kao institucija rađanja zakonite djece vrhunac svoje važnosti doživio za vrijeme Josipa II., prije svega zbog pronatalitne politike koju je car provodio. Stoga ne začuđuju podatci koji govore, između ostaloga, o još jednome zadatku krajiške uprave, a to je briga o udajama seoskih djevojaka.

Tako je Relković 29. studenoga 1784., pred kraj sezone svadbi, poslao regimenti u Vinkovce izvještaj kako se u njegovoj kumpaniji od sto dvadeset i dvije djevojke za udaju udala sto i jedna, a 16 ih se misli udati o pokladama. No, neke su se djevojke odbijale udati, osobito zato što se radilo o dogovornim brakovima. O jednoj djevojci iz Babine Grede Relković govori kako je lijepa i rado mami momke, ali prosce odbija s izlikom kako se još ne može udavati. Obijest lijepe djevojke iziritirala je Relkovića pa ju je pozvao pred kumpanijsku komandu, no ona se ni tamo nije smela, odgovorila je kako će ići kamo je god pošalju, sve radije nego da se uda.

Još je jedan podatak koji govori kako su se slavonske djevojke opirale udaji. Naime, 1784. godine već zaručena djevojka iz Babine Grede pobjegla je, a da nitko nije znao kamo je nestala. Nakon šest tjedana, na sam Badnjak, vratila se kući. Vojna vlast ispitivala ju je gdje je bila, a po njezinu kazivanju bila se sklonila u Piškorevce. Međutim, zbog sumnji

Usp. R. SKenderović, $n$. dj., str. 212. - 213. 
da je bila u Bosni, djevojku i čitavu njezinu obitelj smjestili su u karantenu zbog sigurnosnih razloga. ${ }^{19}$

Ova dva primjera zorno svjedoče kako je glavna zadaća braka bila stvaranje obitelji. Obitelj i bračna zajednica bile su temelj u kojem je pojedinac nastojao zadovoljiti većinu svojih potreba. Osnaživanje obitelji, materijalno i moralno, bilo je u interesu i prosvijećenih vladara.

Josip II. provodio je brojne prosvjetiteljske reforme. Glavni im je smisao bio stvoriti gospodarski jaku i centraliziranu državu te poboljšati položaj podanika. Sigurnost Monarhije ovisila je o dobrome funkcioniranju obitelji, što se najbolje može iščitati na primjeru Vojne krajine. Dvoje ljudi brakom su se udruživali kako bi stvorili nešto novo, od djece, do imovine i posla. Sve navike, vrline i mane stjecale su se unutar obitelji. Kako bi društvo moglo što urednije funkcionirati, instituciju braka trebalo je i pravno regulirati. Stoga je Josip II. obitelj stavio u okvir zakona kako bi uklonio sve ono što je narušavalo ravnotežu i skladne odnose, a time ugrožavalo i samu državu. U tome kontekstu donosi zakon koji će jasnije definirati prava i položaj supružnika, njihove dužnosti, prava i obveze.

\subsection{Zakonska odredba o braku i bračnim odnosima}

U Habsburškoj Monarhiji provodila se odluka Tridentskoga koncila kojom je brak bio u rukama Crkve. Godine 1786. Josip II. donosi patent o braku i bračnim odnosima, tzv. Ženidbenu uredbu.

Država je tim zakonom zašla u dio privatnoga života koji se ticao obitelji i njezina održavanja. Obitelj, brak i bračni odnosi kao i stvaranje potomstva postaju za Josipa II. dio općega javnog interesa. To je i razumljivo jer je sigurnost njegova Carstva počivala na dobro uređenim kućnim zadrugama u Vojnoj krajini u čijoj se osnovi nalazila obitelj. Pored toga nije odbacivao ni ideju o porastu broja stanovnika, što je tada bio opće prihvaćeni trend prosvjetiteljske Europe. Tako da već u uvodnome dijelu Ženidbene uredbe ističe „kako je ženidba dobro za obitelj

Hrvatski državni arhiv Zagreb, fond Brodska satnija, Zapisnik za 17.5. 1783. Usp. T. Matić, Prosvjetni i književni rad..., str. 80. 
i općenito za sve podanike pod njegovom vlašću, dakle i za Dalmaciju, Hrvatsku i Slavoniju“" ${ }^{20}$.

Prvi članak Ženidbene uredbe određuje kako je pravovaljana ženidba jedino ona koja je provedena u skladu s ovim zakonom. Sve se ostale ukidaju, bilo regionalne ili gradske, a Uredba se mora provoditi na prostoru cijele Habsburške Monarhije. ${ }^{21}$ Brak je time postao građanski pravni ugovor, a bračno pravo reguliralo je sve odnose unutar braka. Uredbom su se uređivali načini sklapanja brakova, pravovaljanost zaruka, mogućnosti prava na razvod te prava zakonite i nezakonite djece. Time je država preuzela ulogu Crkve koja je imala glavnu uloga u sklapanju braka sve do pojave racionalizma i prosvjetiteljstva.

Ipak, ako se usporedi katekizam toga doba, primjerice Uputjenja katolicsanska ${ }^{22}$, s ovim zakonom, mogu se primijetiti podudarne osnove crkvenoga i državnoga tumačenja braka u nekim glavnim stavovima. ${ }^{23}$ Stoga često prisutno mišljenje o isključivosti Josipa II. i njegovu

20 StJEPAN SRŠAN, „Ženidbena uredba cara Josipa II. 1787“., Glasnik arhiva Slavonije i Baranje 6., Osijek, 2001., str. 292..

${ }^{21} \quad$ Josip II., Mi Josef Drugi ..., (čl.1.)

22 Preveo Ivan Velikanović (Slavonski Brod, 7. kolovoza 1723. - Vukovar, 21. kolovoza 1803.). Preveo je i tiskao veliki katekizam Upućenja katoličanska autora Francesca Amata Pougeta kojega povijest ubraja među jansenističke pisce. Vidi u: Franjo EMANuel HošKo, „Hrvatska crkvena historiografija o tzv. kasnom jasenizmu u idejnom sustavu jozefinizma“, Scrinia Slavonica: Godišnjak Podružnice za povijest Slavonije, Srijema i Baranje Hrvatskog instituta za povijest, Slavonski Brod, sv. 5., 2005., str. 155. - 157.

${ }^{23}$ „....u Slavoniji je djelovala 'Franjevačka škola' jansenizma i obnove katoličanstva u Slavoniji i Podunavlju. To je bila jansenistička umjerena skupina kojoj je pripadao Ivan Velikanović i Emerik Pavić. Njihova crkvena politika sastojala se od usklađivanja crkvene i svjetovne upravne strukture... Svećenstvu se namijenila uloga državnih činovnika. Sve su se odredbe Crkve u Monarhiji ravnale prema interesima države, a njezine veze s vrhovnom crkvenom vlašću mogle su se uspostavljati samo preko carskog prijestolja. Jansenističko učenje bilo je povezano i s osobitim francuskim sustavom između Crkve i države tzv. galikanizmom. Galikanski teolozi su još u 17. stoljeću razlučili pravni sadržaj braka i njegovo religiozno-sakramentalno značenje. Naglašavali su da svjetovna vlast uređuje bračni ugovor, dok crkvena vlast ima zadaću urediti ono što se odnosi na podjelu sakramentalne ženidbe. Ovo galikansko učenje je bilo osnovica prosvjetiteljskoj filozofiji po kojoj je brak prvenstveno ugovor prirodnog ili građanskog prava pa stoga podliježe uredbama svjetovne vlasti. Sakramentalna stvarnost braka je u nadležnosti Crkve, ali je po svojoj naravi tek pridodano i naknadno uređenje braka po sakramentu ženidbe. Francuski su prosvjetitelji ovo galikansko učenje usmjerili posvemašnjoj laicizaciji braka, što je utjecalo i na patent o ženidbi cara Josipa II.“ Vidi u: F. E. HošKo, „Hrvatska crkvena ..., str. 150., 151., 155. 
apsolutnom priklanjanju racionalizmu pod svaku cijenu na štetu crkvenoga učenja ostaje upitno. Oba pisana dokumenta, i zakon i katekizam, u potpunosti se podudaraju dajući jedinstven odgovor na pitanje što je ženidba, odnosno brak. Zajedničko im je mišljenje kako je osnovna svrha braka stvaranje potomstva, stoga je ženidba društveno zakonita „za uzmloxanje i razplodjenje ${ }^{\text {“24 }_{2}}$. „Ženidbeni je ugovor sklopljen ako muž i žena pristanu da zajedno žive, da mogu rađati djecu i uživati prava koja proizlaze iz toga..." ${ }^{25}$

Novina u pogledu braka odnos je prema razvodu. Prema Uredbi brak je bio nerazdruživ. Međutim, u slučaju da jedna strana nije u mogućnosti izvršavati bračne dužnosti, brak se mogao razvrgnuti pred sudom. Ako je brak razvrgnut, djeca mogu biti i pod skrbništvom oca, a za njihovo izdržavanje obje strane moraju davati proporcionalno. Ako je jedna strana loše postupala s drugom, imaju se pravo pred sudom ili poglavarstvom pogoditi oko razvoda. Ako bi sud dobio pismeno svjedočanstvo svećenika koje sprječava razvod, ne smije ga potvrditi. Razvod je okončan tek kada sud donese odluku o izdržavanju djece. Ako bi se ranije vjenčao jedan od bračnih drugova, kažnjava se svećenik koji je obavio vjenčanje. ${ }^{26}$

Katolička Crkva zastupala je tezu: „Dok nas smrt ne rastavi“. Na ženidbu je gledala kao ugovor ili pogodbu među ljudima sa svrhom rađanja zakonite djece, ali je u kršćanskome duhu ženidbu i brak smatrala sakramentom. Prema tome brak je bio neraskidiv, odnosno „druxtvo nerazvexljivo i neraztavljivo“, što bi značilo da bračne partnere samo smrt može rastaviti. Ponovna ženidba bila je dopuštena i za udovce i udovice i više puta: „Ako se uzdexati nemogu neka se udadu. ${ }^{{ }_{27}}$

Inače, i zakon i crkveno učenje u potpunosti se podudaraju u svim točkama u pogledu zakonitosti braka. Crkveno učenje ne odobrava brak na silu: „Xenidba pak jest ugovor, od svoje naravi slobodan.“ ${ }^{28}$ Takav stav sadržava i Ženidbena uredba: „Koji xensku glavu kojugod sillom odvede,

\footnotetext{
24 Uputjenja katolicsanska, str. 204.

$25 \quad$ S. SRŠAN, $n$. $d j$., str. 290.

${ }_{26}$ Usp. Josip II., Mi Josef Drugi ..., čl.41., čl.42., čl.48., čl.50., čl.59.

${ }_{27}$ Uputjenja katolicsanska, str. 204., 206.

28 Isto, str. 213.
} 
xenidbu valjanu ssnjome ucsiniti nemoxe..." Isto tako, propisuje i da se maloljetne osobe ne smiju zaručiti bez odobrenja roditelja. Ako bi odobrenje bilo uskraćeno, jedna strana mogla se obratiti sudu. ${ }^{29}$

Svadbeni pir kao obvezan dio sklapanja braka kritizirale su i vlasti, ali i književnici onoga doba. Na pretjerano gošćenje, dugo trajanje, raskalašeno i neodgovorno ponašanje upozorava i crkveni nauk. On svadbu promatra kao sveti dan koji se tako mora i provesti: „Kako se pristoji kerstjaninu, neimase po obicsaju neznaboxacah potratiti u igrah, kolah tancanju, i u odvechemu pitju i jishchu. (...) da se necsine pianstva, niti izprazni razgovori, kako i ruxne i necsiste ricsi nebudu.“ ${ }^{30}$

Ženidbena uredba jasno i strogo definira mogućnost sklapanja braka. „Brak se nije smio sklopiti među rodbinom, med detzum dveh bratov ali szeztrih, ili takaj brata, y szeztre tovarustvo biti ne bude moglo.“31 Takav stav zastupala je i Crkva: „Daje nikakva i nevaljala xenidba, akose medju rodajci po kervi tia do csetvertoga kolina rodstva, ucsini...."

Iz svih ovih primjera lako se da naslutiti kako je Josip II., unatoč djelovanjima usmjerenim prema podčinjavanju Crkve državi, ostao vjeran crkveno moralnim postavkama. Ipak treba izdvojiti neke odredbe koje su bile vrlo moderne i nekonvencionalne za ono doba.

Tako se zaruke više nisu smatrale pravno obvezujućim, „naime ukoli-

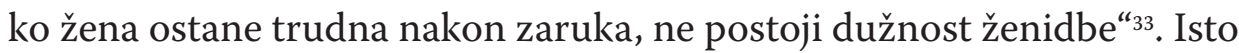
tako, smatrao je da se može zasnovati brak između pripadnika različitih vjera, pri čemu je bilo dovoljno sklopiti brak prema obiteljskomu zakonu, pred svećenikom ili mlade ili mladoženje. ${ }^{34}$

Narušeni bračni odnosi rješavali su se na sudu i za to su bile predviđene stroge kazne, ali ne u okviru odredbi Ženidbene uredbe, već kaznenoga propisa. Za preljub se određivala tjelesna kazna ili tamnica, a nakon odsluženja kazne brak se trebao nastaviti.

\footnotetext{
Josip II., Mi Josef Drugi ..., čl.17., čl.4.

Uputjenja katolicsanska, str. 221.

Josip II., Mi Josef Drugi ..., čl.13.

Uputjenja katolicsanska, str. 211.

S. SRŠAN, $n . d j$., str. 289.

34 Usp. Josip II., Mi Josef Drugi ..., čl.3o.
} 
„Koi drugu zakonite xenidbe po vincsanju zdruxen, sebe s kojom drugom glavom neudatom, illi takogjer udatom puteno smisha, priljubodniszvo csini. Pedepsa jesu udarci, illi s postom tavnica koja udilj pristaje kako strana uvridjena druga u priljubodinstvu ufachena objavi dachega natrag primiti, i s njime u ljubavi vincsanoj xiviti.“. ${ }^{35}$

Kazneni zakon štitio je i djecu. Naime, propisivao je kazne za one trudnice koje su namjerno izazvale pobačaj, bilo da su nešto namjerno popile ili pojele ili na neki drugi način utjecale na to da na svijet donesu mrtvo novorođenče. Predviđene kazne bile su teška tamnica te fizički rad. Za žene koje su udane, a počinile su takav zločin, predviđene su još teže kazne. Kažnjavani su i oni koji su pomagali ženi pobaciti. ${ }^{36}$ Osobita se pažnja poklanjala zaštiti djeteta koje su roditelji ostavili. Kazna je ovisila o mjestu gdje je dijete ostavljeno, teška tamnica propisivala se „ako djteshce u samochu ili u takvo misto postavljeno bilo... da vriskanje njegovo teshkobise csutise moglo...", a lakša „ako pako diteshce na takvu mistu, kuda mloshtvo ljudih obicsaje prolaziti izmetnuto bi bilo..." ${ }^{37}$.

\section{Zaključak}

Josip II. želio je modernizirati Habsburšku Monarhiju, stvoriti sigurnu i dobro organiziranu državu s mnogobrojnim i zadovoljnim podanicima. Najvažnija karika u tome procesu - obitelj, nije predstavljala čvrstu zajednicu, osobito ne u Slavoniji. Posljedice dugotrajne osmanske vlasti bile su vidljive u svakodnevnome životu njezinih stanovnika, o čemu vrlo zorno i slikovito govore književnici i putopisci 18. stoljeća. Podudarnosti u opisima koji kritiziraju slavonske običaje i stil života nisu bile slučajne. Zasigurno su takve pojave uzele velika maha ugrožavajući provedbu mnogih reformi. S druge strane crkveno djelovanje nije bilo dovoljno sveobuhvatno i snažno da ispravi sve društvene nepravilnosti.

Zaostalost i primitivnost naročito su bile vidljive u načinu shvaćanja braka i bračnih obveza. Olako shvaćanje važnosti obitelji i raskalašeni

\footnotetext{
35 Josip II., Opchinska naredba od zlocsinstvah i njihovih pedepsah, Budim, 1788., str. 128., 129., čl. 44., čl. 46.,

36 Usp. isto, str. 67., čl. 112., čl. 113.

37 Isto, str. 68., 69., čl. 115., čl. 117.,
} 
običaji bili su uzrok brojnim problemima: izvanbračna djeca, prisilan brak, nesloga u obitelji.

Josip II. je u svome prosvjetiteljskom djelovanju bio praktičan i životan. Njegove reforme vezane za brak i obitelj zadirale su u crkveno područje zato što je želio ispraviti sve pojave koje nisu bile u skladu $\mathrm{s}$ crkvenim učenjem. Svjetovnu je upravu uskladio s djelovanjem $\mathrm{Cr}$ kve i crkvenom politikom u onolikoj mjeri koliko je zaostalost pojedinih dijelova zemlje to dopuštala. U tome kontekstu treba promatrati i Ženidbenu uredbu kojom je brak stavljen pod nadzor države i u okvir građanskoga zakona. Time su se nastojali prevladati pokrajinski partikularizmi u običajima, osobito oni slavonski koji su bili u suprotnosti s crkvenim naukom, ali i prosvjetiteljskim reformama. Ženidbena uredba je u zakonskome smislu jedinstvena, veoma jasno i pristupačno formulira bračne obveze, dužnosti i prava supružnika unutar braka, ali i obitelji. U svojim nastojanjima da stvori što zdravije društvo, Josip II. pokazao je razboritost i umjerenost. Iako je brak stavio pod jurisdikciju države, njegovo temeljno promišljanje o braku i dalje je bilo blisko crkvenomu učenju. Zakonskim regulativama cilj je bio postići uređenije i pravednije društvo, ne oduzimajući braku onu ulogu koju je imao i ranijih stoljeća.

\section{Literatura:}

- Benvin, Anton, „Obitelj kroz povijest“, Bogoslovska smotra, Zagreb, god. XLII. (1972.), br. 1., str. 46.

- DošEn, VId - Ivanošıć, Antun, Izabrana djela, Privlačica, Vinkovci, 1994.

- HošKo, Franjo Emanuel, „Hrvatska crkvena historiografija o tzv. kasnom jansenizmu u idejnom sustavu jozefinizma", Scrinia Slavonica: Godišnjak Podružnice za povijest Slavonije, Srijema i Baranje Hrvatskog instituta za povijest, sv. 5., Slavonski Brod, 2005., str. 150. - 157.

- Hrvatski državni arhiv Zagreb, fond Brodska satnija, Zapisnik za 17.5. 1783 . 
- Josıp II., Mi Josef Drugi (...), Nacionalna i sveučilišna knjižnica u Zagrebu, Zbirka rijetkosti, knj. Kušević, LIV A 9/2 adl 4, 1786.

- Josip II., Opchinska naredba od zlocsinstvah $i$ njihovih pedepsah, Budim, 1788.

- Matić, Tomo, Slavonske književno - povijesne teme, Riječ, Vinkovci, 2003.

- Matić, Tomo, Prosvjetni i književni rad u Slavoniji prije preporoda, Slavonsko selo u djelima hrvatskih pisaca potkraj osamnaestoga vijeka, Privlačica, Vinkovci, 1994.

- Relković, Matija Antun, Satir iliti divji čovik, Kraljevska zemaljska tiskara, Zagreb, 1909.

- Skenderović, Robert, Najstarija matična knjiga brodske župe Presvetog Trojstva (1701.-1735.), Hrvatski institut za povijest, Podružnica za povijest Slavonije, Srijema i Baranje, Slavonski Brod, 2012.

- SRŠAn, StJePAN, „Ženidbena uredba cara Josipa II. 1787.“, Glasnik arhiva Slavonije i Baranje, Osijek, god. VI., 2001., str. 288. - 289.

- Taube, Friedrich Wilhelm Von, Istorijski i geografski opis Kraljevine Slavonije i Vojvodstva Srijema, Leipzig, 1777., Petrović, BošKo (prev.) Matica srpska, Subotica, 1998.

- Velikanović, Ivan (prev), Uputjenja katolicsanka po Francesku Amatu Pougetu, 3. dio, Tiskara Ivana Martina Divalt, Osijek, 1788., Nacionalna i sveučilišna knjižnica u Zagrebu, R II E-8o - 2. 
Original scientifc article Received on November 6, 2020 Accepted on March 11, 2021

IVANČICA MARKOVIĆ

Josip Juraj Strossmayer University of Osijek, Faculty of Education

\title{
INFLUENCES OF THE ENLIGHTENMENT ON FAMILY, MARRIAGE AND MARITAL RELATIONS IN THE HABSBURG MONARCHY
}

\begin{abstract}
The paper analyzes Slavonian habits and customs related to family, marriage and marital relations in the $18^{\text {th }}$ century. The author uses descriptions from travelogue and literary works as well as descriptions from the original archive materials. They are compared to Joseph II's legal regulation on marital relations and catechism. The author also analyzes the possible existence of interconnection of the Slavonian morals and adopting the marriage edict of the Emperor Joseph II, or in other words if the legal regulation was only a consequence of comprehensive enlightenment reforms.
\end{abstract}

Keywords: marriage; family; marital relations; laws; Habsburg Monarchy 